\title{
What determines a productive winter bean-wheat genotype combination for intercropping in central Germany?
}

\author{
W.C.D. Nelson ${ }^{\text {a,e, } 1, *}$, D.J. Siebrecht-Schöll ${ }^{\text {b,e,1 }}{ }^{\text {, M.P. Hoffmann }}{ }^{\text {a,c }}$, R.P. Rötter ${ }^{\text {a,e }}$, A. \\ M. Whitbread ${ }^{\mathrm{d}}$, W. Link ${ }^{\mathrm{b}}$ \\ ${ }^{a}$ Georg-August-Universität Göttingen, Tropical Plant Production and Agricultural Systems Modelling (TROPAGS), Grisebachstraße 6, 37077 Göttingen, Germany

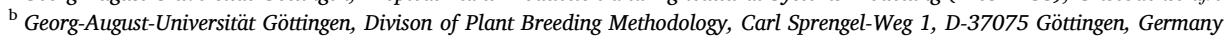 \\ ${ }^{\mathrm{c}}$ AGVOLUTION GmbH, Göttingen \\ ${ }^{\mathrm{d}}$ International Crops Research Institute for the Semi-Arid Tropics (ICRISAT), IITA East Africa Hub, Dar es Salaam, Tanzania \\ ${ }^{\mathrm{e}}$ Georg-August-Universität Göttingen, Center of Biodiversity and Sustainable Land Use (CBL), Büsgenweg 1, 37077 Göttingen, Germany
}

\section{A R T I C L E I N F O}

\section{Keywords:}

Vicia faba

Triticum aestivum

Intercropping

Overyielding

Trait expression

\begin{abstract}
A B S T R A C T
Little is known about optimising the productivity of intercropping through exploiting differences between genotypes. Our study evaluates the performance of three winter wheat cultivars and eight winter faba bean genotypes (experimental inbred lines) sown as replacement row intercrops with sole cropping comparisons. Detailed agronomic, physiological and soil-based measurements were taken over three consecutive autumn-sown seasons at two sites (a marginal versus a fertile soil) in central Germany. This study aimed to contribute to our understanding of key traits required to achieve highly complementary and well-performing intercrops.

Faba bean plus wheat intercrops yielded higher than sole crop equivalents at both sites, but more so at the marginal site $(34 \%>12 \%)$. High intercrop yields were associated with high wheat component yields. Such stands included faba bean genotypes that exhibited low leaf area index (LAI) values and low plant height. Tall and large faba beans i.e. with high vegetative biomass led to excessive lodging, both as a sole crop and when intercropped. To some extent, this concealed effects of faba bean genotype trait variation that would have otherwise been visible had lodging not occurred. The expression of these traits was heavily influenced by variation in environmental conditions. At the less fertile site, even tall intercropped faba beans showed relatively lower vegetative biomass, which promoted intercropped wheat and led to superior overyielding values and relative yield total.

While site-specific differences are key, German winter faba beans need further genetic improvement to refrain from superfluous biomass growth when water resources are plentiful.
\end{abstract}

\section{Introduction}

Cereal-legume intercropping is an approach that works towards more sustainable agricultural landscapes (Fletcher et al., 2016). This is in part due to the potential for higher yields when compared to sole crop equivalents (intercrop performance compared with that of the two sole cropped species on the same area of land) especially when external inputs, such as nitrogen $(\mathrm{N})$ fertilisers are few or lacking (Bedoussac and Justes, 2010; Malézieux et al., 2009). Intercrop yield advantages are referred to as the 'mixing effect' (Hof-Kautz and Rauber, 2003), 'overyielding' (Li et al., 2011, 2014; Streit et al., 2019) or 'Relative Yield Total' sometimes called 'Land Equivalent Ratio' (Weigelt and Jolliffee, 2003). Such yield advantages are typically related to the complementary use of resource niches and tend to be higher under stress (Fargione and Tilmann, 2005; Hector et al., 2002). For example, root length density enhancement (Schröder and Köpke, 2012; Meinen et al., 2019) might contribute to overyielding, or a complex canopy structure might do so via the establishment of more favourable microclimates that potentially reduce soil moisture evaporation (Tsubo and Walker, 2004). Cereal-legume intercrops therefore have the highest potential for

\footnotetext{
* Corresponding author at: Georg-August-Universität Göttingen, Tropical Plant Production and Agricultural Systems Modelling (TROPAGS), Grisebachstraße 6, 37077, Göttingen, Germany.

E-mail address: wnelson@gwdg.de (W.C.D. Nelson).

1 WCDN and DSS contributed equally to this manuscript.
} 
overyielding in low input environments. A well-known example of such a system is the ancient maize-bean-squash polyculture of Mesoamerica that takes advantage of complementary canopy development through the establishment of various leaf layers for light interception (Postma and Lynch, 2012).

Production advantages, whether based on yield or resource-use efficiency, result from temporally asynchronous resource exploitation of different crop species (Hauggaard-Nielsen and Jensen, 2001). Several studies have highlighted that cereals rely more on soil inorganic $\mathrm{N}$ (Jensen, 1996) than legumes - cereals do not have the alternative $\mathrm{N}$-source that legumes have through symbiosis (Hauggaard-Nielsen et al., 2003). This forces the intercropped legume to rely more than its pure stand on its symbiotic $\mathrm{N}_{2}$ fixation (Hauggaard-Nielsen and Jensen, 2001).

For decades, most arable crops have been bred with sole cropping in mind, which is why breeding results may not necessarily be optimal for intercropping (Hauggaard-Nielsen and Jensen, 2001). While research has indeed looked at niche complementarity for spring crops, little information is available for winter crops (Bedoussac and Justes, 2010). The development of a truly efficient winter intercrop is therefore unique. In a recent review on intercropping, Brooker et al. (2015) argued that plant breeding and experimentation with crop combinations is likely to have the highest potential to increase the resource use efficiency of intercrops.

The typical sowing period for grain legumes for northern Europe is spring, especially in Germany and further east where harsher winters prevail (Jensen et al., 2010); the main danger for autumn sown pulses being winter kill (Link et al., 2010). However, recent research on faba bean has shown success towards more winter-hardy germplasm (Ali et al., 2016; Arbaoui and Link, 2008; Flores et al., 2012; Landry et al., 2015, 2016). There are many advantages of winter legumes over the spring types (Flores et al., 2012). Their head start in terms of below-ground biomass development means that substantial growth can be achieved even before spring types have become well established. Autumn sowing also intends on making better use of the soil moisture available during the winter months, potentially avoiding drought later in the season - a particular threat for grain yield stability (Flores et al., 2012; Khan et al., 2010; Neugschwandtner et al., 2019).

Intercropping will be judged as successful not only if total grain yield of the intercrop stand is higher than the sole crop equivalents, but also by intercrop complementarity. Examples are improved $\mathrm{N}$ and water use. Complementarity is often linked to low input cereal-legume cultivation (Pristeri et al., 2006). The grain legume faba bean is a successful component when intercropped with wheat (Hof-Kautz et al., 2007; Pristeri et al., 2006). Our study was built on this research and aimed to evaluate the performance of three winter wheat cultivars and eight winter faba bean genotypes (experimental inbred lines) sown as sole and intercrop stands. This is also in line with recent calls for plant breeding programmes to develop crops for specific systems (Varshney et al., 2018). While the overyielding potential of intercrop stands is well known, our study aimed to contribute towards explaining why, i.e. what leads to overyielding and, more generally, what drives high bean-plus-wheat intercrop yields.

This study looked at key agronomic traits, such as leaf area index (LAI) and plant height over three seasons of field trials at two separate sites in central Germany with contrasting soils.

The following hypotheses were formulated:

(1) Intercrop stands lead to higher yield than sole crop stand equivalents (i.e. higher than the average of the corresponding sole crop stands).

(2) Intercrops perform better under marginal soil conditions than on soils that offer deeper rooting, more water and higher $\mathrm{N}$ supply.

(3) There is a genotype effect on the yield performance of the intercrop stands, which is related to canopy development and functional traits.

\section{Materials and methods}

\subsection{Study site}

The field experiment was conducted at two experimental stations of the Georg-August-Universität, Göttingen in Niedersachsen, Germany. Reinshof, at $51^{\circ} 29^{\prime} \mathrm{N}, 9^{\circ} 55^{\prime} \mathrm{E}$, at $157 \mathrm{~m}$ above sea level (ASL), and Deppoldshausen at $51^{\circ} 34^{\prime} \mathrm{N}, 9^{\circ} 58^{\prime} \mathrm{E}$ at $342 \mathrm{~m}$ ASL. The climate is maritime to continental, with higher rainfall in the summer months. Annual rainfall averages $630 \mathrm{~mm}$ for the Göttingen area (Deutscher Wetterdienst records 1961-2016). Average annual rainfall during the experimental period (2014-17) was $637 \mathrm{~mm}$ and $592 \mathrm{~mm}$ for Reinshof and Deppoldshausen, respectively (Heshmati et al., 2020).

Field trials were conducted over three seasons, 2014-15, 2015-16 and 2016-17 at both sites. Reinshof is located in a valley and characterised as a Gleyic Fluvisol (WRB). Top soil contained $21 \%$ clay, $11 \%$ sand, and $68 \%$ silt in the Ah horizon. Deppoldshausen is located on a hill where the soil is shallow $(30-40 \mathrm{~cm})$ and high in rock content. The marginal soil of this site has an Ah horizon of $25 \mathrm{~cm}$ depth and is characterised as a Calcaric Leptosol. The clay content is higher with 34 $\%$ clay, $2 \%$ sand, and $55 \%$ silt (Heshmati et al., 2020). Fig. 1 showcases examples of the two soil profiles, Deppoldshausen (i) and Reinshof (ii).

\subsection{Genetic material and experimental design}

Eight experimental winter faba bean (Vicia faba L.) inbred lines and three winter wheat (Triticum aestivum L.) cultivars were used for this experiment. Winter faba bean genotypes were chosen from the NPZ (Norddeutsche Pflanzenzucht Hans-Georg Lembke KG, Hohenlieth, Germany) breeding programme and that of the department for Crop Sciences, University of Göttingen (Roth and Link, 2009). They were chosen because of their differences in plant height, grain yield and physiological stage development, such as time to flowering and time to maturity (Table 1). The three winter wheat cultivars were released from European breeding companies that are part of the German Seed Alliance: line cultivars Genius (Ta1) and Boxer (Ta2), and hybrid cultivar Hybery (Ta3). These wheat cultivars were chosen because of their resistance against major pathogens, such as fusarium and mildew, as well as known agronomic differences, such as plant height and seed protein content (Bundessortenamt, 2015).

For detailed trait assessment, different sets of entries were used due to the large size of the experiment and consequential budget constraints. The full set of entries (FSE) included all winter faba bean genotypes and winter wheat cultivars grown as sole crops and all 24 intercrop stand combinations between the eight winter faba bean genotypes and three winter wheat cultivars. Grain yield is reported from the FSE. The reduced set of entries (RSE) included the eight winter faba bean

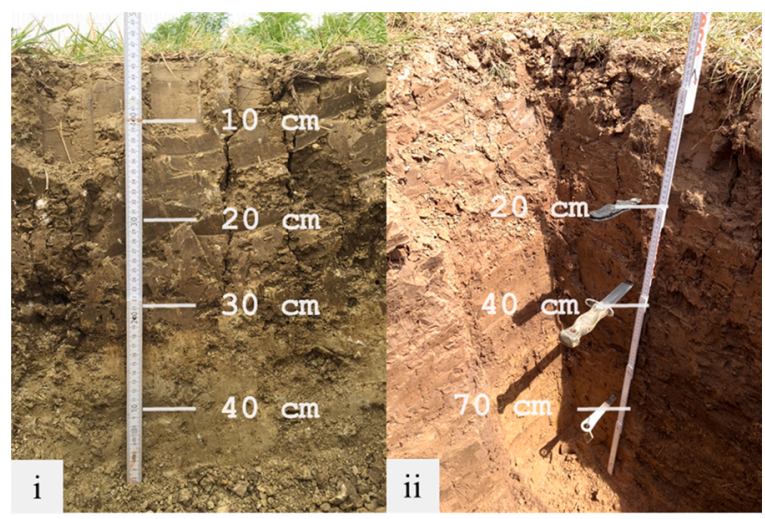

Fig. 1. Soil profiles of Deppoldshausen (i) and Reinshof (ii). The ruler within the soil profile pits highlights the shallow (Deppoldshausen, 0-40 cm) and deep (Reinshof, 0-100 cm) characteristics of each soil. 
Table 1

Winter faba bean genotypes included in the experiment with some known characteristics phenotyped prior to the field experiment.

\begin{tabular}{|c|c|c|}
\hline Code & Genotype & Characteristics \\
\hline Vf1 & S_004-1-6 & $\begin{array}{l}\text { Medium tall, low tillering, late flowering, medium } \\
\text { maturing, high yielding }\end{array}$ \\
\hline Vf2 & S_062-2-2 & $\begin{array}{l}\text { Very short, high tillering, medium early flowering, } \\
\text { medium maturing }\end{array}$ \\
\hline $\mathrm{Vf} 3$ & S_069-1-1 & $\begin{array}{l}\text { Very tall, medium tillering, medium late flowering, } \\
\text { medium maturing, high yielding }\end{array}$ \\
\hline Vf4 & S_265-1-1 & $\begin{array}{l}\text { Very tall, very high tillering, medium early flowering, } \\
\text { medium maturing }\end{array}$ \\
\hline Vf5 & Hiverna/2-5-1 & $\begin{array}{l}\text { Medium tall, low tillering, medium early flowering, low } \\
\text { yielding, pure line developed from Hiverna (German } \\
\text { cv.), superior winter hardiness }\end{array}$ \\
\hline Vf6 & $\begin{array}{l}\text { Côte d'Or/ } 1-1- \\
3\end{array}$ & $\begin{array}{l}\text { Very tall, high tillering, late flowering, late maturing, } \\
\text { source of superior winter hardiness }\end{array}$ \\
\hline Vf7 & $\begin{array}{l}\text { WAB- } \\
\text { Fam157-1-2 }\end{array}$ & $\begin{array}{l}\text { Medium tall, low tillering, early flowering, early } \\
\text { maturing, high yielding }\end{array}$ \\
\hline Vf8 & $\begin{array}{l}\text { WAB- } \\
\text { EP98-267-11 }\end{array}$ & $\begin{array}{l}\text { Medium tall, medium tillering, late flowering, late } \\
\text { maturing, high yielding, sibling of former cv. Nordica }\end{array}$ \\
\hline
\end{tabular}

genotype sole crop stands and the sole crop stands of the winter wheat cultivar Genius (Ta1), as well as the eight corresponding intercrop stand combinations. Winter wheat cultivar Genius was chosen here because of its medium plant height, high $\mathrm{N}$-uptake capacity, low susceptibility to mildew and rather stable yields (Bundessortenamt, 2015). Results for LAI, plant height, lodging and soil measurements are shown from the RSE stands alone.

The field trials were part of the IMPAC ${ }^{3}$ project (https://www.uni -goettingen.de/de/528191.html) and set up as a split-plot design with four blocks (replicates). The rotation crop prior to the onset of this experiment was winter wheat in Reinshof and oilseed rape in Deppoldshausen. Later, winter rye was grown as the previous crop throughout. While grain yield of the previous crop was taken from the field, straw was tilled into the soil. The main plot factor was defined by the eight winter faba bean genotypes and the split-plot factor was the cropping system. The eight winter faba bean genotypes and three winter wheat cultivars were grown in sole crop stands and in alternating row intercrop stands. This resulted in 140 plots per site, i.e. 280 plots per season (Siebrecht-Schöll, 2019). Each plot covered a total area of $27 \mathrm{~m}^{2}$ to allow for various samples and measurements.

In intercrop stands, each species was sown at $50 \%$ of its sole stand seed density (replacement or substitutive intercrop design). Faba bean sole crop stands were sown with 40 seeds per $\mathrm{m}^{2}$ and wheat sole crop stands with 320 seeds per $\mathrm{m}^{2}$. The between row distance was $22.5 \mathrm{~cm}$ for all stands. Seeds were sown untreated; plots were sown with 12 rows.

The two intercrop components were sown simultaneously, along with the sole crop stands, between the 30th of September and the 29th of October, depending on the season (Table S1). The last $\mathrm{N}$ fertiliser application took place in 2013 at both sites. Although no N fertiliser was applied, a base application of $\mathrm{P}, \mathrm{K}$, and $\mathrm{Mg}$ was given. Fungicides and insecticides were used when a serious threat of crop stand failure occurred. In this instance, all crops were treated. Pre-emergence herbicides were used and manual weeding conducted within the vegetation period.

\subsection{Plant and soil sampling}

A combine harvester was used between the 9th and the 20th of August (Table S1) to harvest a central part per plot of $10.5 \mathrm{~m}^{2}$, consisting of six rows with three buffer rows remaining at either side of each plot. In addition to this grain yield harvest, crop phenology was monitored using the $\mathrm{BBCH}$ scale. Plant height of each species and LAI per plot using an AccuPAR LP-80 ceptometer was measured for the RSE (eight bean genotypes, Genius, and their intercrop stands). Leaf area index of each plot was measured four times during the key vegetative production phases in each season, between April and the end of July. Plant height was measured per species in all stands four times within the vegetation period: before flowering, start of flowering, full flowering, and after flowering of the winter faba beans. The mean of ten representative plants per plot was used for the analysis. Lodging was scored per species as and when it occurred on a scale of one to nine (no lodging to severe lodging). In intercrop stands, bean and wheat were scored separately for plant height and lodging. Lodging score dates were as follows: 10th of July 2015 (both sites), and the 30th of July for Reinshof only; 27th and the 28th of May 2016 (both sites); and the 4th of July 2017 (both sites).

Soil sampling for soil water and mineral $\mathrm{N}$ content $\left(\mathrm{N}_{\min }\right)$ was conducted manually at full flowering and one day after harvest (Table S1) using a soil auger. Soil samples were only taken in the first and second seasons (2014-15 and 2015-16). Soil profile depths at the two sites differed, going to a depth of $0-90 \mathrm{~cm}$ in Reinshof, divided into three $30 \mathrm{~cm}$ layers, and $0-30 \mathrm{~cm}$ in Deppoldshausen (Fig. 1). Three soil core samples were taken for each plot sampled and layers mixed in a bucket from which subsamples for soil water and for $\mathrm{N}_{\min }$ were taken for analysis. Soil water subsamples were weighed directly in the field, dried in ovens at $105^{\circ} \mathrm{C}$ for $48 \mathrm{~h}$ and weighed. Mineral N subsamples were directly stored in cool boxes before photometric $\mathrm{N}_{\min }$ analyses (Flow Solution III, Alpkem, Wilsonville, Oregon) via the $\mathrm{CaCl} 2$ method (VDLUFA, 1991). Extractable soil water was calculated using the soil water measurements described above together with the soil-specific lower limit and bulk density values derived from the Niedersächsischen Bodeninformationssystems (Lower Saxony Soil Information Systems, NIBIS: https://www.lbeg.niedersachsen.de/kartenserver).

\subsection{Data analysis}

Results were first checked for normal distribution of residuals before identifying significant differences. The effects of system, site, and faba bean genotype on yield and physiological traits were analysed using linear models ( $R$, version 3.4.3; plotted using ggplot2). Data was analysed separately based on fixed effects: system, genotype, and site (dependent on the level of analysis and question). P-values are displayed as $0.1 \%$ '***', $1 \%$ '**”, and $10 \%$ '*'. When analyses of variance showed significance, a post hoc test (Tukey, adjusted for multiple comparisons using the Holm method) was applied for differences between groups. For the traits LAI and plant height, maximum values were used for analysis. For example, LAI measurements were taken from four replicates per site four times within the vegetative period for each season. Replicates were averaged for each of the four sampling events. The highest (maximum) mean values were used.

\section{Results}

\subsection{Yield}

Total grain yield was significantly higher for intercrop stands than for sole crop equivalents at both sites. The highest yields for both intercrop and sole crop stands were in Reinshof (Fig. 2). The difference between intercrop and sole crop stands, however, was $513 \mathrm{~kg} \mathrm{ha}^{-1}$ greater $(983>470)$ in Deppoldshausen than in Reinshof; Deppoldshausen is the more marginal site in terms of soil conditions (Table 2). The average for relative yield total varied according to the wheat cultivar from 1.020 to 1.233 , the general mean was 1.220 . This parameter was on average 1.346 in Deppoldshausen and 1.094 in Reinshof.

There is an overall trend that the highest total intercrop yield was associated with high wheat component yield (Fig. 3). This is seen at both sites, although to a greater extent and with a higher range at Reinshof (Fig. 4). The intercrop combinations Ta3-Vf7 (4,214 $\mathrm{kg} \mathrm{ha}^{-1}$ ) and Ta3Vf3 $\left(4,207 \mathrm{~kg} \mathrm{ha}^{-1}\right)$ ranked first and second in Deppoldshausen (Table 3). They ranked second $\left(5,095 \mathrm{~kg} \mathrm{ha}^{-1}\right)$ and third $\left(5,021 \mathrm{~kg} \mathrm{ha}^{-1}\right)$ in Reinshof. The high-yielding intercrop combinations tended to involve the same bean genotypes, regardless of the wheat cultivar (Table 3). 


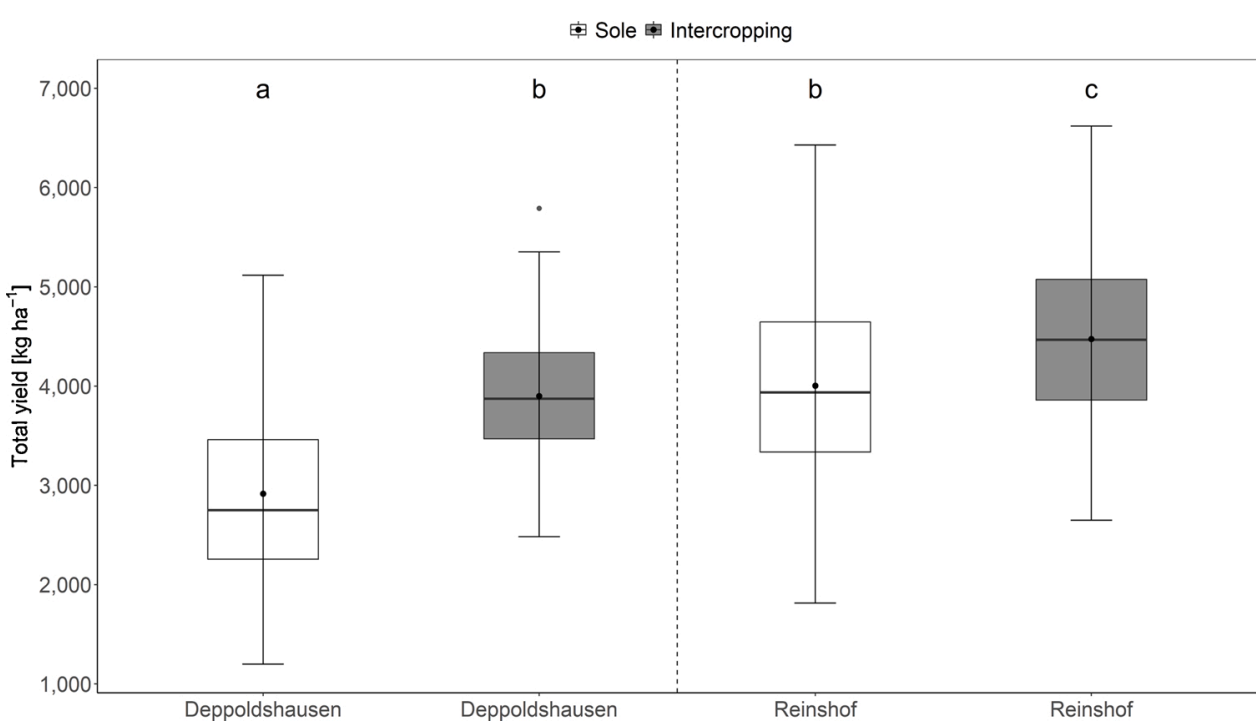

Fig. 2. Total grain yield of all 24 FSE intercrop combinations compared to their equivalent sole crop means for both sites across all three seasons. The three horizontal lines indicate the 75 $\%$ percentile (up), median (solid line across boxes) and $25 \%$ percentile yield (bottom); the upper and lower bars outside the boxes show the maximum and minimum values respectively. Significant differences (across all environments) are shown through the lower case letters. The isolated point is an outlier. The dashed line separates the sites.
Table 2

Within site system differences for yield, means across seasons. The system difference was highly significant at both sites. P-values are displayed as $0.1 \%$ '***; $1 \%$ ‘**”, and $10 \%$ ‘*”.

\begin{tabular}{llll}
\hline Site & System & $\begin{array}{l}\text { Mean yield }(\mathrm{kg} \\
\left.\mathrm{ha}^{-1}\right)\end{array}$ & $\begin{array}{l}\text { System difference } \mathrm{kg} \\
\left.\mathrm{ha}^{-1}\right)\end{array}$ \\
\hline Deppoldshausen & $\begin{array}{l}\text { Intercrop } \\
\text { stands } \\
\text { Sole crop } \\
\text { stands }\end{array}$ & 3,899 & $983 * * *$ \\
Reinshof & $\begin{array}{l}\text { Intercrop } \\
\text { stands } \\
\text { Sole crop } \\
\text { stands }\end{array}$ & 4,474 & \\
\hline
\end{tabular}

An association between bean component yield and the total yield of intercrops existed in Deppoldshausen only (with Ta2, $r=0.83^{*}$; Fig. S1). The corresponding associations in intercrops with Genius and Hybery at Deppoldshausen and with all three wheats at Reinshof were small $(0.19<\mathrm{r}<0.51)$ and not significant.

Bean component yields were, as expected, negatively correlated with wheat component yields. Across all 24 mixtures, these correlation were, $\mathrm{r}=-0.85 * * *$ and $\mathrm{r}=-0.92 * * *$ in Deppoldshausen and Reinshof, respectively. Correspondingly, in both sites, increases in the wheat component yields were associated with increases in the total yields, with correlation values across all 24 mixtures of $r=0.69 * * *$ for Deppoldshausen and $\mathrm{r}=0.83 * * *$ for Reinshof (Fig. 4). The positive association between wheat component yield and total yield was strong and consistent, whereas the negative association between bean component yield and total yield was very small and not significantly different from zero.
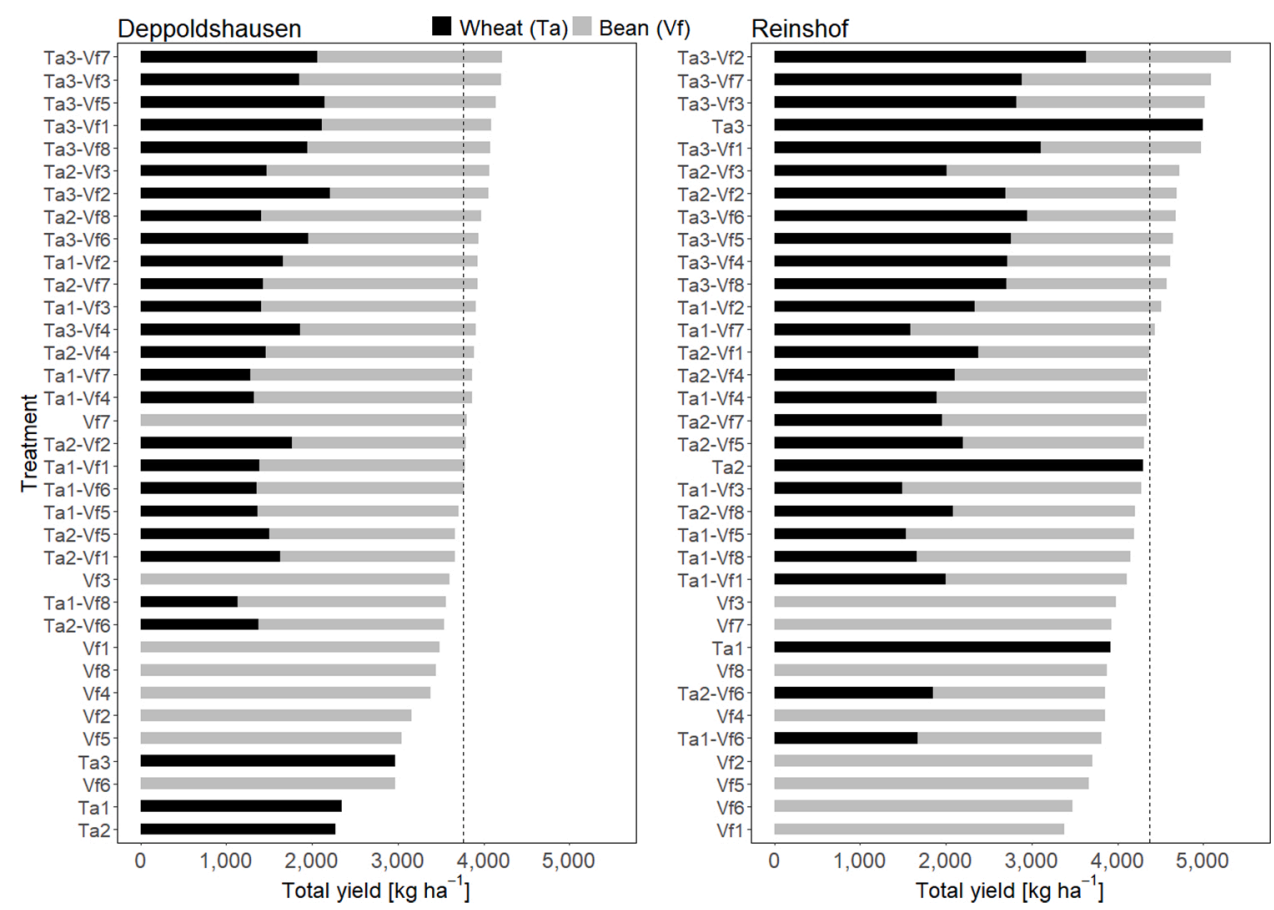

Fig. 3. Total yield for each FSE combination for both sites. Total yield is shown from the highest (top) to the lowest (bottom). Bars represent means of four replicates across three seasons. Wheat component yields and bean component yields are identified through the colours black and grey, respectively. The dashed line marks the mean total yield. 

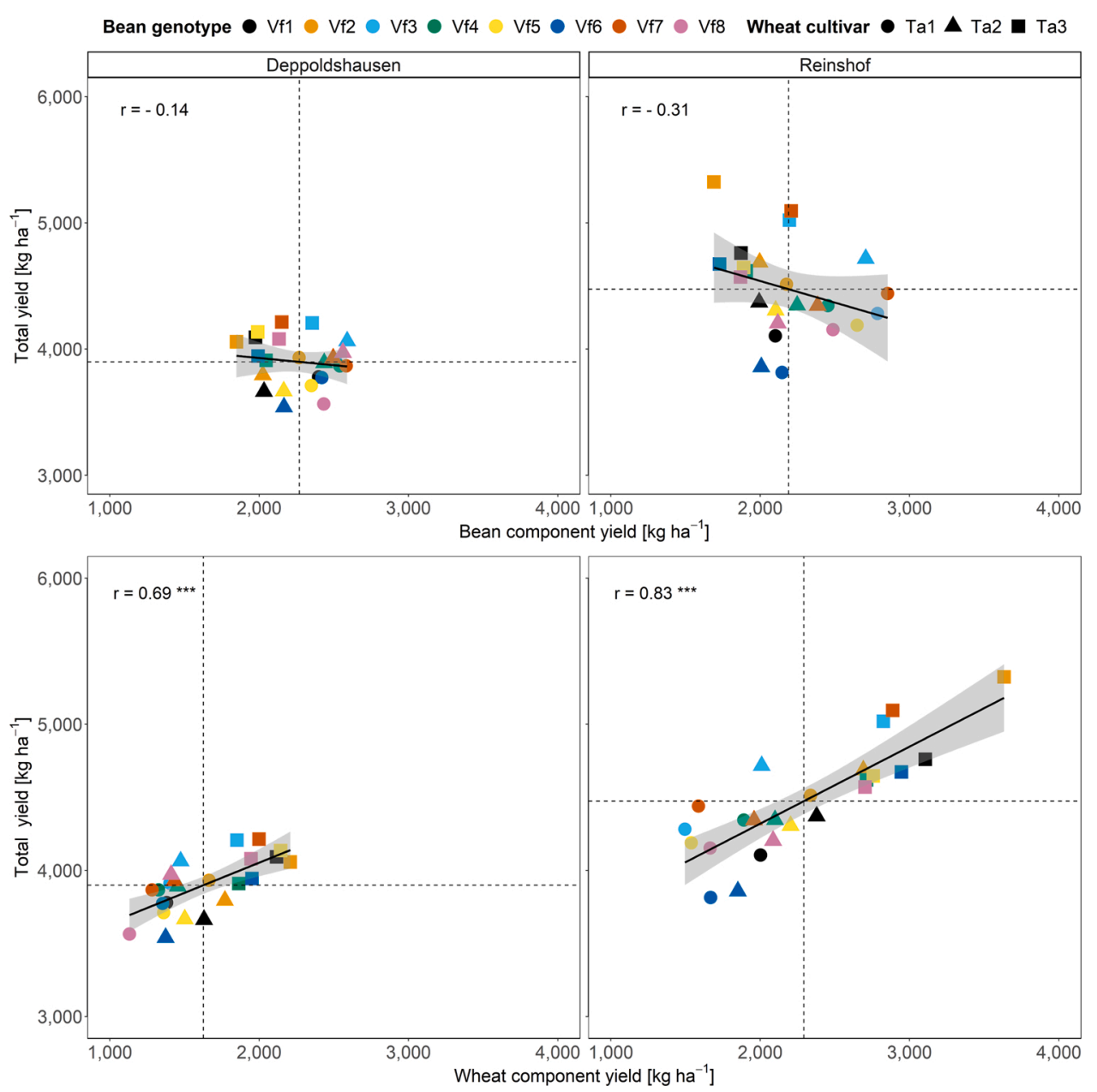

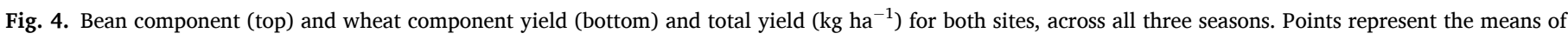

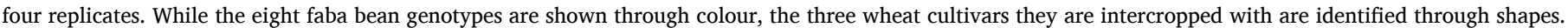
Dashed lines mark the mean values.

High bean component yields in Deppoldshausen were only as high as average bean component yields in Reinshof. High wheat component yields in Deppoldshausen corresponded to below average levels in Reinshof (Fig. 4). Total yields tended to be high when wheat crops were a vigorous and high yielding component of their intercrop stand and beans rather weak.

\subsection{Physiological traits: leaf area index, plant height and lodging}

There was a strong positive correlation between the intercrop (with wheat cultivar Genius) and sole crop LAI values of the eight bean genotypes across seasons in both sites, with values of $r=0.98 *$ for Deppoldshausen and $r=0.80 * *$ for Reinshof (details not shown). The LAI ranking of the eight bean genotypes was the same in Deppoldshausen and Reinshof, although at different levels of LAI, i.e. there was a clear site effect yet little genotype $\mathrm{x}$ site effect. Similar to the pattern of yield (Fig. 4), a high intercrop LAI value in Deppoldshausen was a low intercrop LAI value in Reinshof.

In Deppoldshausen, the higher the LAI was the lower the total yield, whereas in Reinshof no association was observed (Fig. S2). Total yield was highest in Reinshof (Ta1-Vf2), albeit with the genotype combination that produced the second lowest LAI in that site. Intercrop combinations that exhibited low LAI achieved high total yields in both sites.

As an exception, wheat was taller than the mean of the beans for five intercrop combinations in Deppoldshausen in the first season. In the five other environments, wheat was shorter than the beans on average for nearly all combinations. The exceptions were the intercrops with bean genotype Vf2 (Fig. S3). In the second season, faba beans grew markedly taller than wheat at both sites (mean height difference: $17 \mathrm{~cm}$ in Deppoldshausen; $29 \mathrm{~cm}$ in Reinshof). In this second season, intercrop combination Ta1-Vf2 was the highest yielding at both sites. This intercrop stand combination included the shortest growing bean (Fig. S3); hence there was the smallest height difference between the bean and wheat intercrop components. Average wheat component yields $\left(2,627 \mathrm{~kg} \mathrm{ha}^{-1}\right)$ were higher than average bean component yields $\left(1,555 \mathrm{~kg} \mathrm{ha}^{-1}\right)$ in season three only, which experienced the highest total yields out of all three seasons - average total yields were $4,004 \mathrm{~kg}$ $\mathrm{ha}^{-1}, 3,862 \mathrm{~kg} \mathrm{ha}^{-1}$ and 4,182 $\mathrm{kg} \mathrm{ha}^{-1}$ for the first, second and third year respectively (Fig. S3).

The eight faba bean genotypes lodged in the first and third seasons with averages of 1.69 and 3.90 (intercrop), and 2.75 and 2.00 (sole crop). Wheat lodged less, with averages across all three seasons of 1.67 and 1.06 for Genius in intercrop and sole crop stands. The extent of lodging in the first and third seasons did not impact yield (Fig. 5).

In the second season (2015-16), the average lodging score for the bean sole crop stands was 4.97 for Deppoldshausen and 6.72 for Reinshof. Bean genotype Vf8 as a sole crop stand lodged the most at both sites with scores of 7.25 and 8.50 (Fig. 5). The short growing faba bean Vf2 lodged the least in both sites with scores below 3.30; Vf2 lodging was not high enough to negatively impact yield. The intercrop stands of these two faba beans lodged accordingly, in Deppoldshausen with scores of 1.83 (Vf2) and 4.58 (Vf8), in Reinshof with scores of 2.41 (Vf2) and 7.50 
Table 3

Total yield means across seasons for top performing intercrop stands. Ranked in each site for Hybery, Boxer, Genius intercrop combinations separately. The top three are displayed, respectively. Yields are means of the four replicates. Intercrop component yield percentages of total yield are given alongside the total yield.

\begin{tabular}{|c|c|c|c|}
\hline Site & $\begin{array}{l}\text { Intercrop } \\
\text { combination }\end{array}$ & $\begin{array}{l}\text { Percentages of component } \\
\text { yield (wheat; bean) }\end{array}$ & $\begin{array}{l}\text { Total yield } \\
\left(\mathrm{kg} \mathrm{ha}^{-1}\right)\end{array}$ \\
\hline & \multicolumn{3}{|c|}{ Intercrop stands with Hybery (Ta3) } \\
\hline \multirow{4}{*}{ Deppoldshausen } & Ta3-Vf7 & $49 ; 51$ & 4,214 \\
\hline & Ta3-Vf3 & $44 ; 56$ & 4,207 \\
\hline & Ta3-Vf5 & $52 ; 48$ & 4,135 \\
\hline & Ta3-Vf2 & $68 ; 32$ & 5,324 \\
\hline \multirow[t]{4}{*}{ Reinshof } & Ta3-Vf7 & $57 ; 43$ & 5,095 \\
\hline & Ta3-Vf3 & $56 ; 44$ & 5,021 \\
\hline & \multicolumn{3}{|c|}{ Intercrop stands with Boxer (Ta2) } \\
\hline & Ta2-Vf3 & $36 ; 64$ & 4,063 \\
\hline \multirow[t]{3}{*}{ Deppoldshausen } & Ta2-Vf8 & $36 ; 64$ & 3,972 \\
\hline & Ta2-Vf7 & $36 ; 64$ & 3,928 \\
\hline & Ta2-Vf3 & $43 ; 57$ & 4,717 \\
\hline \multirow[t]{4}{*}{ Reinshof } & Ta2-Vf2 & $57 ; 43$ & 4,687 \\
\hline & Ta2-Vf1 & $54 ; 46$ & 4,371 \\
\hline & \multicolumn{3}{|c|}{ Intercrop stands with Genius (Ta1) } \\
\hline & Ta1-Vf2 & $42 ; 58$ & 3,932 \\
\hline \multirow[t]{3}{*}{ Deppoldshausen } & Ta1-Vf3 & $36 ; 64$ & 3,912 \\
\hline & Ta1-Vf7 & $33 ; 67$ & 3,867 \\
\hline & Ta1-Vf2 & $52 ; 48$ & 4,514 \\
\hline \multirow[t]{2}{*}{ Reinshof } & Ta1-Vf7 & $36 ; 64$ & 4,440 \\
\hline & Ta1-Vf4 & $44 ; 56$ & 4,344 \\
\hline
\end{tabular}

(Vf8). The higher scores of faba bean genotype Vf8 caused a reduction of harvestable grain yield.

There was a positive correlation between the canopy height of plots and the severity of lodging in both sites. Jointly considering the eight intercrop and the eight sole bean crop stands, the correlations were $\mathrm{r}=0.62 *$ in Deppoldshausen and $\mathrm{r}=0.84 * *$ in Reinshof (Fig. 5). There was also a positive correlation between the LAI and the severity of lodging in both sites, with $r=0.85 * * *$ for Deppoldshausen and $r=0.62$ * for Reinshof. As with canopy height, the eight bean genotypes ranked similarly for lodging and for LAI in both sites. High lodging scores of the 2015-16 season were negatively correlated with grain yield, which included the eight intercrop and the eight bean sole crop stands; $r=$ $0.88 * * *$ for Deppoldshausen, $r=-0.68 * *$ for Reinshof (details not shown).

\subsection{Soil water and nitrogen}

Reinshof had a much higher amount of extractable soil water than Deppoldshausen due to the root zone being three times deeper. Mean values at full flowering were $141 \mathrm{~mm}>18 \mathrm{~mm}$ and at final harvest $158 \mathrm{~mm}>31 \mathrm{~mm}$ ) (Fig. 6). Reinshof was clearly the more fertile site in terms of physical and chemical soil properties. Mineral $\mathrm{N}$ content in both sites was higher at the harvest time than at full flowering. The mean value increased in Deppoldshausen from 16 to $24\left(\mathrm{~kg} \mathrm{ha}^{-1}\right)$ and in Reinshof from 10 to $15\left(\mathrm{~kg} \mathrm{ha}^{-1}\right)$. Mineral $\mathrm{N}$ content was higher at both sampling dates in Deppoldshausen than in Reinshof.

\section{Discussion}

Intercropping winter faba bean with winter wheat is uncommon, in part due to well established and successful protocols for high input sole cropping (Fletcher et al., 2016), which is based on the availability of affordable $\mathrm{N}$ fertiliser that does not need $\mathrm{N}$-symbiosis-based fertility (Peoples et al., 2019). Climate change projections predict mild winters, summer droughts and in general an unclear future (Rötter et al., 2018). There is therefore a need for more 'tools' and ways in which such unpredictability can be dealt with, encouraging the use of crops like winter faba bean in crop rotations. With agricultural policy advocating for high resource use efficiency and ecological intensification, such winter cereal-legume intercrops are likely to be part of our future agricultural landscapes (Stomph et al., 2020).

\subsection{Winter bean-wheat intercrop performance}

This study clearly highlighted site-specific magnitudes of overyielding. While the intercrop stands yielded higher than the sole crop stands at both sites, the performance difference between the systems at

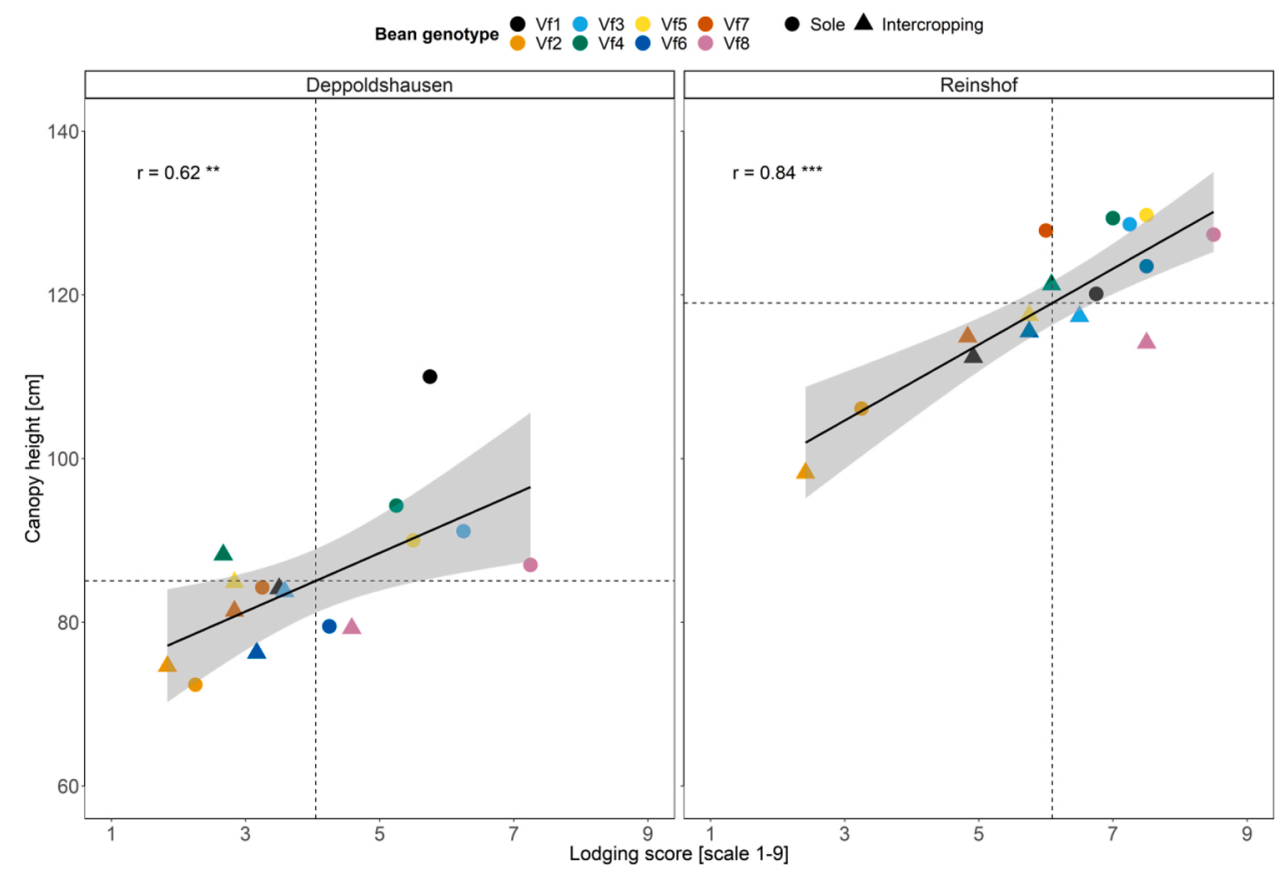

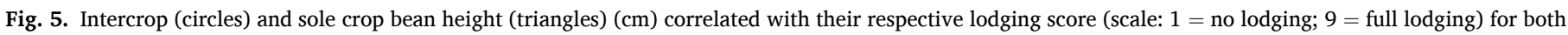
sites and shown from one season (2015-16). Dashed lines mark the mean values. 

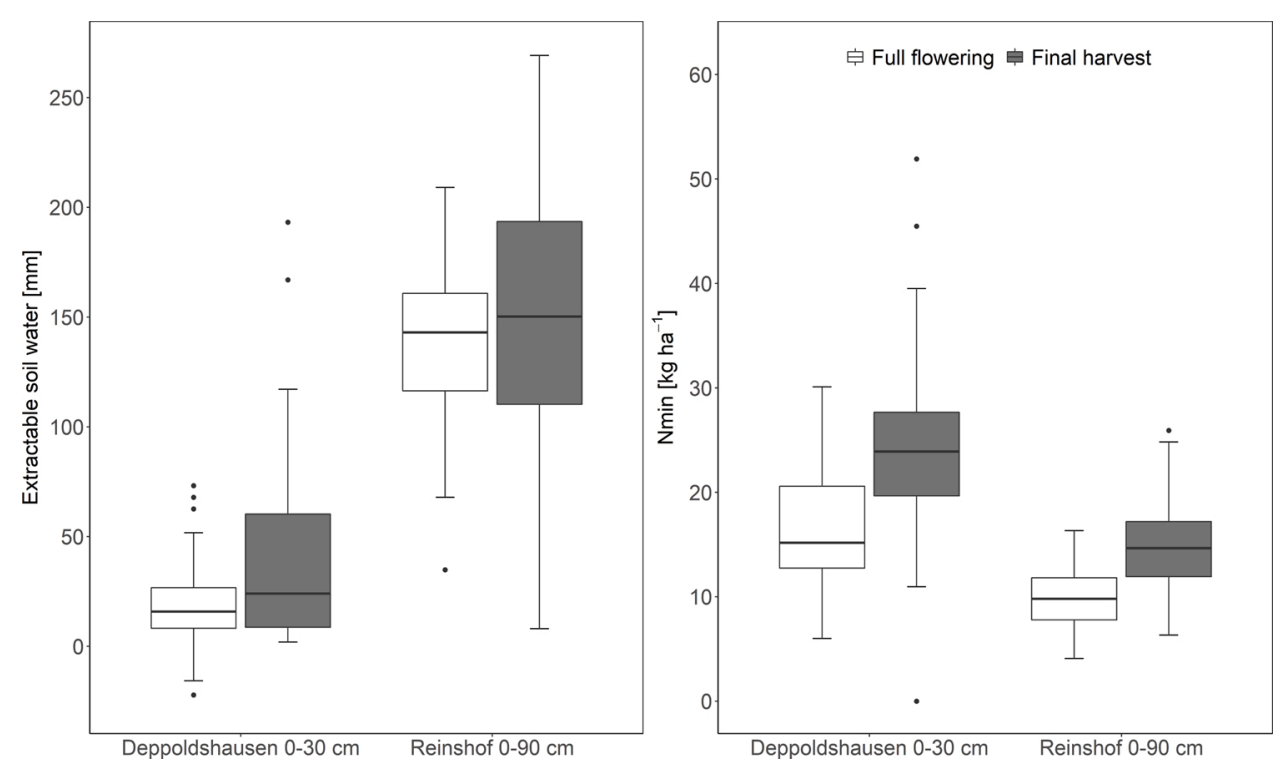

Fig. 6. Extractable soil water and content of available mineralised nitrogen $\left(\mathrm{N}_{\min }\right)$ of all intercrop stands at full flowering and final harvest for two seasons (2014-15 and 2015-16). For each site the extractable soil water and $\mathrm{N}_{\min }$ content of each layer $(0-30,30-60$, and 60$90 \mathrm{~cm}$ ) was summed within each replicate. The three horizontal lines indicate the $75 \%$ percentile (top), median (solid line across boxes) and $25 \%$ percentile yield (bottom); the upper and lower bars outside the boxes extend to the maximum and minimum values respectively. The isolated points are outliers. the marginal site Deppoldshausen was more than double that of Reinshof (Fig. 2), confirming hypothesis one and two of this study (intercrop stands yield higher than sole crops equivalents; intercrops perform better under marginal conditions). Improved performance under marginal conditions can be examined across various ecological scenarios. Skinner et al. (2004) found the overyielding of grass-clover mixtures to decrease under favourable weather conditions compared to normal and dry conditions. Similar responses have also been found with forest species, where mixing species led to overyielding of $66 \%$ on poor sites, $35 \%$ on mediocre sites, and $12 \%$ on fertile sites (Pretzsch, 2013).

Quantification of the intercrop component contributions to total yield (Fig. 3) showed that the highest yielding intercrop combinations yielded more wheat component yield than bean component yield. This was especially the case in Reinshof, which had higher amounts of soil water (Fig. 6). While it is widely known that wheat performs well with comparatively high N supply (Jensen, 1996; Hauggaard-Nielsen et al., 2003), the markedly higher relative yield total in Depoldshausen compared to Reinshof $(1.346>1.094)$ was partly due to low sole crop wheat yields in Deppoldshausen and the comparatively high sole crop wheat yields in Reinshof (Fig. 3). Faba beans were also limited by the soil water content in Deppoldshausen (Fig. 6). The resulting relatively short and weak beans did not compete strongly with their wheat intercrop partner, therefore supporting wheat component growth. Regardless of the mechanism, the highest total yields were dependant on the wheat component. Very convincingly, the highest yielding wheat cultivar Hybery (Ta3) was responsible for the high yields of its intercrop stands (Figs. 4 \& S1). Intercrop combinations with lower wheat component yield allowed for a higher bean component yield, although this resulted in lower total yield. In summary, the gain of bean component yield, allowed by weaker wheats (Ta1, Ta2) did not compensate for the loss of the wheat contribution to total yield. The intercrop combinations that resulted in the three highest wheat component yields (Table S2; Fig. S1) yielded more total yield than the intercrop combinations that gave the three highest bean component yields. This was true in Deppoldshausen $\left(4,095 \mathrm{~kg} \mathrm{ha}^{-1}>3,967 \mathrm{~kg} \mathrm{ha}^{-1}\right)$ and in Reinshof $\left(4,992 \mathrm{~kg} \mathrm{ha}^{-1}>4\right.$, $480 \mathrm{~kg} \mathrm{ha}^{-1}$ ).

Soil characteristics dictated the expression of traits such as LAI, plant height and lodging of faba beans. The second season experienced an unfavourable excess of these traits. Fertile soil characteristics, such as sufficient water availability, lead this germplasm to exaggerate vegetative growth. Genetic modernisation to avoid such trait expression was realised in spring bean breeding following the seminal report of Dantuma et al. (1983) and the corresponding employment of semi-dwarf types for breeding, such as the Minica cultivar. Similar advancement is needed for northern European winter bean germplasm.

The higher relative yield total $(1.346>1.094)$ of the marginal site Deppoldshausen compared to Reinshof follows a pattern known from heterotic yield increase from hybrid cultivars. It is well known that heterosis is more pronounced under marginal conditions: hybrids tend to suffer less under stress than the inbred lines (Abdelmula et al., 1999; Einfeldt et al., 2005). Here, overyielding due to mixing two components is probably caused by an increased difference in the use of limited resources, such as water; variation in quantity as well as timing (Fig. 6).

\subsection{Traits characteristics, resource competition, and implications for breeding}

Data showed an LAI effect due to site, with low values in Deppoldshausen and high values in Reinshof (Fig. S2). Increases in LAI were associated with reductions of total yield in Deppoldshausen. Faba bean was largely responsible for high LAI, which indicates that it outcompeted wheat for light. In Reinshof, LAI showed zero association with yield. Increases in LAI without yield increases are not resource efficient.

Although tall faba beans yielded higher than short faba beans on average, yield differences were minimal (Fig. S3). Height per se was therefore not that important for high faba bean yields. For wheat as an intercrop component, plant height in relation to the faba bean component's plant height was decisive. The shorter the wheat component was compared to the bean component, the more yield it lost. The lowest wheat component yields were recorded in the second season when intercropped faba beans grew taller than the wheat, in particular in Reinshof (Fig. S3). This indicates that there was a genotype effect on the total yield, driven by a bean genotype specific canopy, as phrased in hypothesis three. A similar trend was also found by Nelson et al. (2018), where sole cropped pearl millet yields (of a short cultivar) were lower when intercropped with an erect cowpea cultivar. The bean genotypes were a highly significant source of variation for the total yield of their mixtures (Siebrecht-Schöll, 2019), yet, bean component yield was barely associated with the total yield (Fig. S2).

Differences in lodging were a major driver of differences in harvestable yield in this experiment. Although Vf2 was the bean component of the highest yielding intercrop combinations in the 2015-16 season, this result was mainly due to these stands being the most harvestable ones, as they lodged the least (Fig. 5). While faba bean Vf8 may well have produced more grain (as a sole crop and an intercrop), its yield could barely be collected by the combine harvester due to 
heavy lodging. Lodging differences between faba bean genotypes were expressed to a greater extent at the more fertile site of Reinshof.

Fertile soils can support excessive biomass development that can lead to shading of intercropped wheat and intercrop stand lodging. On a fertile soil, the use of a shorter faba bean (moderate LAI, low tendency to lodge) could ensure good bean and wheat intercrop yields (Fig. 3). In the experiment presented, faba bean genotype Vf2 stood out as it expressed limited LAI values (Figs. S2) and was the shortest (Fig. S3). This genotype was also part of the highest ranked intercrop stands for total yield for both sites - although more so in Reinshof - regardless of the wheat cultivar it was intercropped with (Fig. 3; Table 3). Working towards biomass stability across diverse environments is a key challenge for faba bean breeders (Dantuma et al., 1983).

\subsection{Perspectives for winter bean-wheat intercropping}

An optimal scenario for winter bean-wheat intercropping would include a highly fertile site that is able to support high wheat and faba bean yields. However, this study proposed that northern European winter faba beans need further improvement to be successful in such environments and under the management implemented. Where water resources were plentiful, increases in biomass production were not followed by increases in yield, but instead taller faba beans increased the risk of lodging for the entire stand. The successful adoption of winter bean-wheat intercropping will probably be based on already well established wheat cultivars, such as those used in this experiment. Winter faba bean genotypes should therefore be bred to suit such modern wheat cultivars, which have already been bred to be short and not lodge (Damisch and Wiberg, 1991). Breeders could partly substitute breeding shorter faba beans with selecting genotypes that lodge less due to other physiological traits, such as stiffer stems (Sass and Stelling, 1990). Simply breeding for shorter faba beans could lead to lower yields (Link and Stuetzel, 1995), due, for example, to a reduction in the photosynthetic capacity of a canopy (Peng et al., 2014). Major support for breeding is expected through linking modelling and field experimentation, which was an inherent part of the overarching IMPAC ${ }^{3}$ study setup within which this field experiment was conducted. This support should be realised, for example, through ex ante analyses of genotype $x$ environment $\mathrm{x}$ management interactions (Rötter et al., 2018). Sufficiently winter hardy faba bean genotypes with high LAI and high plant height but low lodging risk do not currently exist. Crop simulation models however, can disentangle such syndromes in silico to allow for better-informed breeding.

The application of site-specific knowledge could help farmers and society benefit from winter bean-wheat intercropping beyond overyielding (Fig. 2; Table 2). Higher grain legume production would lead to less reliance on imports, increased ecosystem services such as higher $\mathrm{N}$ content in the soil and increased soil organic carbon levels (Hoffmann et al., 2020). A recent study estimated that the increased $\mathrm{N}$ use efficiency of intercropping could reduce fossil-based $\mathrm{N}$ fertiliser by about $26 \%$ on a global scale (Jensen et al., 2020).

\section{Conclusion}

While this study has shown that winter bean-wheat intercropping led to higher yields under low input management than sole crop equivalents, it also highlighted key traits that are required to ensure highyielding intercrops. Adequate leaf area index, limited canopy height, and non-lodging of faba bean are key traits for high performing beanwheat intercrops. Considering the current available genotypes of winter faba bean, marginal sites are better cultivated with rather vigorous bean genotypes, while fertile sites require shorter ones. This strategy works to ensure that excessive faba bean biomass does not outcompete wheat for light or potentially lead to excessive lodging, therefore ensuring good wheat component yields. Winter faba beans should be bred to restrain from excess vegetative biomass development under more fertile conditions.

\section{CRediT authorship contribution statement}

W.C.D. Nelson: Conceptualization, Data curation, Visualization, Formal analysis, Writing - original draft, Writing - review \& editing. D.J. Siebrecht-Schöll: Conceptualization, Investigation, Formal analysis, Writing - original draft. M.P. Hoffmann: Conceptualization, Data curation, Visualization, Writing - original draft. R.P. Rötter: Writing original draft. A.M. Whitbread: Writing - original draft. W. Link: Funding acquisition, Conceptualization, Project administration, Formal analysis, Writing - original draft.

\section{Declaration of Competing Interest}

The authors report no declarations of interest.

\section{Acknowledgements}

This study was conducted within the IMPAC ${ }^{3}$ project (grant number 031 A351A), coordinated by the Centre of Biodiversity and Sustainable Land Use of the University of Göttingen, Germany. The project was funded by the German Federal Ministry of Education and Research (BMBF). We thank our project partners the Deutsche Saatveredelung (DSV) and the Norddeutsche Pflanzenzucht (NPZ) for the provision of genetic material. We are immensely grateful for the work of Regina Martsch for managing all aspects of the field experiment. W.C.D.N. received support from the BMBF via the 'SALLnet' project (grant number 01LL1802A) within the SPACES2 Program. R.P.R. is grateful for financial support from FACCE-JPI (Suscrop - ERA - Net) of the European Union via the BARISTA project (grant number 031B0811A). A.M.W. acknowledges support from the CGIAR Research Programs on Climate Change, Agriculture and Food Security (CCAFS) carried out with support from the CGIAR Trust Fund and through bilateral funding agreements. For details please visit https://www.cgiar.org/funders/.

\section{Appendix A. Supplementary data}

Supplementary material related to this article can be found, in the online version, at doi:https://doi.org/10.1016/j.eja.2021.126294.

\section{References}

Abdelmula, A.A., Link, W., von Kittlitz, E., Stelling, D., 1999. Heterosis and inheritance of drought tolerance in faba bean, Vicia faba L. Plant Breed. 118, 485-490. https:// doi.org/10.1046/j.1439-0523.1999.00411.x.

Ali, M.B.M., Welna, G.C., Sallam, A., Martsch, R., Balko, C., Gebser, B., Sass, O., Link, W., 2016. Association analysis to genetically improve drought and freezing tolerance of faba bean (Vicia faba L.). Crop Sci. 56, 1036-1048. https://doi.org/10.2135/ cropsci2015.08.0503.

Arbaoui, M., Link, W., 2008. Effect of hardening on frost tolerance and fatty acid composition of leaves and stems of a set of faba bean (Vicia faba L.) genotypes. Euphytica 162, 211-219. https://doi.org/10.1007/s10681-007-9521-4.

Bedoussac, L., Justes, E., 2010. The efficiency of a durum wheat-winter pea intercrop to improve yield and wheat grain protein concentration depends on $\mathrm{N}$ availability during early growth. Plant Soil 330, 19-35. https://doi.org/10.1007/s11104-0090082-2.

Brooker, R.W., Bennett, A.E., Cong, W.F., Daniel, T.J., George, T.S., Hallett, P.D., Hawes, C., Iannetta, P.P.M., Jones, H.G., Karley, A.J., Li, L., McKenzie, B.M., Pakemann, J., Paterson, E., Schöb, C., Shen, J., Squire, G., Watson, C.A., Zhang, C., Zhang, F., Zhang, J., White, P.J., 2015. Improving intercropping: a synthesis or research in agronomy, plant physiology and ecology. New Phytol. 206, 107-117. https://doi.org/10.1111/nph.13132.

Bundessortenamt (Ed.), 2015. Beschreibende Sortenliste, Getreide, Mais, Öl- Und Faserpflanzen, Leguminosen, Rüben, Zwischenfrüchte. Landbau-Verlagsgesellschaft Hannover, Germany.

Damisch, W., Wiberg, A., 1991. Biomass Yield - a topical issue in modern wheat breeding programmes. Plant Breed. 107, 11-17. https://doi.org/10.1111/j.1439-0523.1991. tb00523.x.

Dantuma, G., von Kittlitz, E., Frauen, M., Bond, D.A., 1983. Yield, yield stability and measurements of morphological and phenological characters of faba bean (Vicia faba L.) varieties grown in a wide range of environments in Western Europe. Results of the EC Joint Faba Bean Trials. J. Plant Breed. 90, 85-105. 
Einfeldt, C.H.P., Ceccarelli, S., Grando, S., Gland-Zwerger, A., Geiger, H.H., 2005. Heterosis and mixing effects in barley under drought stress. Plant Breed. 124 https:// doi.org/10.1111/j.1439-0523.2005.01111.x, 350-350.

Fargione, J., Tillman, D., 2005. Niche differences in phenology and rooting depth promote coexistence with a dominant $\mathrm{C}_{4}$ bunchgrass. Oecologia 143, 598-606. https://doi.org/10.1007/s00442-005-0010-y.

Fletcher, A.L., Kirkegaard, J.A., Peoples, M.B., Robertson, M.J., Whish, J., Swan, A.D., 2016. Prospects to utilise intercrops and crop variety mixtures in mechanised, rainfed, temperate cropping systems. Crop Pasture Sci. 67, 1252-1267. https://doi.org/ 10.1071/CP16211.

Flores, F., Nadal, S., Solis, I., Winkler, J., Sass, O., Stoddard, F.L., Link, W., Raffiot, B., Muel, F., Rubiales, D., 2012. Faba bean adaptation in autumn sowing under European climates. Agron. Sustain. Dev. 32, 727-734. https://doi.org/10.1007/ s13593-012-0082-0.

Hauggaard-Nielsen, H., Jensen, E.S., 2001. Evaluating pea and barley cultivars for complementarity in intercropping at different levels of soil $\mathrm{N}$ availability. Field Crops Res. 72, 185-196. https://doi.org/10.1016/S0378-4290(01)00176-9.

Hauggaard-Nielsen, H., Ambus, P., Jensen, E.S., 2003. The comparison of nitrogen use and leaching in sole cropped versus intercropped pea and barley. Nutr. Cycl. Agroecosystems 65, 289-300. https://doi.org/10.1023/A:1022612528161.

Hector, A., Bazeley-White, E., Loreau, M., Otway, S., Schmid, B., 2002. Overyielding in grassland communities: testing the sampling effect hypothesis with replicated biodiversity experiments. Ecol. Lett. 5, 502-511. https://doi.org/10.1046/j.14610248.2002.00337.x.

Heshmati, S., Tonn, B., Isselstein, J., 2020. White clover population effects on the productivity and yield stability of mixtures with perennial ryegrass and chicory. Field Crops Res. 252, 107802 https://doi.org/10.1016/j.fcr.2020.107802.

Hoffmann, M.P., Swanepoel, C.M., Nelson, W.C.D., Beukes, D.J., van der Laan, M., Hargreaves, J.N.G., Rötter, R.P., 2020. Simulating medium-term effects of cropping system diversification on soil fertility and crop productivity in southern Africa. Eur. J. Agron. 119, 126089 https://doi.org/10.1016/j.eja.2020.126089.

Hof-Kautz, C., Rauber, R., 2003. Growing Crop Mixtures in Organic Farming. German. Published by the National Program for Organic Farming at the Federal Institute for Agriculture and Human Nutrition, Bonn and Göttingen, p. 55. ISBN 3-00-011733011734.

Hof-Kautz, C., Hochmuth, C., Schmidtke, K., Rauber, R., 2007. Wirkung des Gemengeanbaus mit Winterkörnerleguminosen sowie der Standraumzuteilung auf Kornertrag und Backqualität von Winterweizen (effects of intercropping with winter grain legumes and spatial arrangement on grain yield and baking quality of winter wheat). In: Zikeli, S., Claupein, W., Dabbert, S., Kaufmann, B., Müller, T., Valle Zárate, A. (Eds.), Zwischen Tradition und Globalisierung, Beiträge zur 9. Wissenschaftstagung Ökologischer Landbau, Band 1. Universität Hohenheim, Deutschland, pp. 121-124 in German. http://orgprints.org/10742.

Jensen, E.S., 1996. Rhizode position of $\mathrm{N}$ by pea and barley and its effect on soil $\mathrm{N}$ dynamics. Soil Biol. Biochem. 28, 65-71. https://doi.org/10.1016/0038-0717(95) 00116-6.

Jensen, E.S., Peoples, M.B., Hauggaard-Nielsen, H., 2010. Faba bean cropping systems. Field Crops Res. 115, 203-216. https://doi.org/10.1016/j.fcr.2009.10.008.

Jensen, E.S., Carlsson, G., Hauggaard-Nielsen, H., 2020. Intercropping of grain legumes and cereals improves the use of soil $\mathrm{N}$ resources and reduces the requirement for synthetic fertilizer N: a global-scale analysis. Agron. Sustain. Dev. 40, 5. https://doi. org/10.1007/s13593-020-0607-x.

Khan, H.R., Paull, J.G., Siddique, K.H.M., Stoddard, F.L., 2010. Faba bean breeding for drought-affected environments: a physiological and agronomic perspective. Field Crops Res. 115, 279-286. https://doi.org/10.1016/j.fcr.2009.09.003.

Landry, E.J., Lafferty, J.E., Coyne, C.J., Pan, W.L., Hu, J., 2015. Registration of four winter-hardy faba bean germplasm lines for use in winter pulse and cover crop development. J. Plant Regist. 9, 367-370. https://doi.org/10.3198/ jpr2014.12.0087crg.

Landry, E.J., Coyne, C.J., McGee, R.J., Hu, J., 2016. Adaptation of autumn-sown Faba bean germplasm to south eastern Washington. Agron. J. 108, 301-308. https://doi. org/10.2134/agronj2015.0028.

Li, Q.-Z., Sun, J.-H., Wei, X.-J., Christie, P., Zhang, F.-S., Li, L., 2011. Overyielding and interspecific interactions mediated by nitrogen fertilization in strip intercropping of maize with faba bean, wheat and barley. Plant Soil 339, 147-161. https://doi.org/ 10.1007/s11104-010-0561-5.

Li, L., Tilman, D., Lambers, H., Zhang, F.-S.-, 2014. Plant diversity and overyielding: insights from belowground facilitation of intercropping in agriculture. New Phytol. 203, 63-69. https://doi.org/10.1111/nph.12778.

Link, W., Stützel, H., 1995. Faba bean. Genetics. In: Diepenbrock, W., Becker, H.C. (Eds.), Physiological Potentials for Yield Improvement of Annual Oil and Protein Crops. Advances in Plant Breeding 17, Blackwell, Berlin, pp. 239-278.

Link, W., Balko, C., Stoddard, F.L., 2010. Winter hardiness in faba bean: physiology and breeding. Field Crops Res. 115, 287-296. https://doi.org/10.1016/j. fcr.2008.08.004.
Malézieux, E., Crozat, Y., Dupraz, C., Laurans, M., Makowski, D., Ozier-Lafontaine, H., Rapidel, B., de Tourdonnet, S., Valantin-Morison, M., 2009. Mixing plant species in cropping systems: concepts, tools and models. Agron Sustain Dev. 29, 43-62. https://doi.org/10.1051/agro:2007057.

Meinen, C., Streit, J., Rauber, R., 2019. Intercropping effects on root distribution of eight novel winter faba bean genotypes mixed with winter wheat. Field Crops Res. 235, 1-10. https://doi.org/10.1016/j.fcr.2019.02.014.

Nelson, W.C.D., Hoffmann, M.P., Vadez, V., Rötter, R.P., Whitbread, A.M., 2018. Testing pearl millet and cowpea intercropping systems under high temperatures. Field Crops Res. 217, 150-166. https://doi.org/10.1016/j.fcr.2017.12.014.

Neugschwandtner, R.W., Bernhuber, A., Kammlander, S., Wagentristl, H., KlimekKopyra, A., Kaul, H.-P., 2019. Agronomic potential of winter grain legumes for Central Europe: development, soil coverage and yields. Field Crops Res. 241, 107576 https://doi.org/10.1016/j.fcr.2019.107576.

Peng, D., Chen, X., Yin, Y., Lu, K., Yang, W., Tang, Y., Wang, Z., 2014. Lodging resistance of winter wheat (Triticum aestivum L.): lignin accumulation and its related enzymes activities due to the application of paclobutrazol or gibberellin acid. Field Crops Res. 157, 1-7. https://doi.org/10.1016/j.fcr.2013.11.015.

Peoples, M.B., Hauggaard-Nielsen, H., Huguenin-Elie, O., Jensen, E.S., Justes, E., Williams, M., 2019. Agroecosystem Diversity, Agriculture and Environmental. Chapter 8 - The Contributions of Legumes to Reducing the Environmental Risk of Agricultural Production, pp. 123-143. https://doi.org/10.1016/B978-0-12-8110508.00008-x.

Postma, J.A., Lynch, J.P., 2012. Complementarity in root architecture for nutrient uptake in ancient maize/bean and maize/bean/squash polycultures. Ann. Bot. 110, 521-534. https://doi.org/10.1093/aob/mcs082.

Pretzsch, H., 2013. Facilitation and competition in mixed-species forests analyzed along an ecological gradient. Nova Acta Leopoldina NF 114, 159-174.

Pristeri, A., Dahlmann, C., von Fragstein, P., Godding, M.J., Hauggaard-Nielsen, H., Kasyanova, E., Monti, M., 2006. Yield performance of faba bean- wheat intercropping on spring and winter sowing in European organic farming systems. Poster at: Joint Organic Congress, Odense, Denmark. May 30-31, 2006.

Roth, F., Link, W., 2009. Selektion Auf Frosttoleranz Von Winterackerbohnen (Vicia Faba L.): Methodenoptimierung Und Ergebnisse Selection on Freezing-tolerance of Faba Bean (Vicia Faba L.): Improvement of Methods and Results. Lehr- Und Forschungszentrum Fuer Landwirtschaft, Raumberg-gumpenstein. 60. Tagung Der Vereinigung Der Pflanzenzuechter Und Saatgutkaufleute Oesterreiches 2009, pp. 31-37.

Rötter, R.P., Appiah, M., Fichtler, E., Kersebaum, K.C., Trnka, M., Hoffmann, M.P., 2018. Linking modelling and experimentation to better capture crop impacts of agroclimatic extremes - a review. Field Crops Res. 221, 142-156. https://doi.org/ 10.1016/j.fcr.2018.02.023.

Sass, O., Stelling, D., 1990. Influence of Different Plant Types on Harvestability and Yield of Faba Beans, Vicia faba L. Mutation Breeding Newsletter. International Atomic Energy Agency (IAEA): IAEA, p. 44.

Schröder, D., Köpke, U., 2012. Faba bean (Vicia faba L.) intercropped with oil crops - a strategy to enhance rooting density and to optimize nitrogen use and grain production? Field Crops Res. 135, 74-81. https://doi.org/10.1016/j. fcr.2012.07.007.

Siebrecht-Schöll, D., 2019. Breeding Analysis of Eight Winter Faba Bean Genotypes for Mixed Cropping With Winter Wheat. PhD thesis. http://hdl.handle.net/21.11130/00 -1735-0000-0005-128E-7.

Skinner, R.H., Gustine, D.L., Sanderson, M.A., 2004. Growth, water relations, nutritive value of pasture species mixtures under moisture stress. Crop Sci. 44, 1361-1369. https://doi.org/10.2135/cropsci2004.1361.

Stomph, T., Dordas, C., Baranger, A., de Rijk, J., Dong, B., Evers, J., Gu, C., Li, L., Simon, J., Jensen, E.S., Wang, Q., Wang, Y., Wang, Z., Xu, H., Zhang, C., Zhang, L., Zhang, W.-p., Bedoussac, L., van der Werf, W., 2020. Chapter one - designing intercrops for high yield, yield stability and efficient use of resources: are there principles? Adv. Agron. 160, 1-50. https://doi.org/10.1016/bs.agron.2019.10.002.

Streit, J., Meinen, C., Nelson, W.C.D., Siebrecht-Schöll, D., Rauber, R., 2019. Above- and belowground biomass in a mixed cropping system with eight novel winter faba bean genotypes and winter heat using FTIR spectroscopy for root species discrimination. Plant Soil 436, 141-158. https://doi.org/10.1007/s11104-018-03904-y.

Tsubo, M., Walker, S., 2004. Shade effects of Phaseolus vulgaris L. Intercropped with Zea mays L. Under well-watered conditions. J. Agron. Crop. Sci. 190, 168-176. https:// doi.org/10.1111/j.1439-037X.2004.00089.x.

Varshney, R.K., Thundi, M., Pandey, M.K., Tardieu, F., Ojiewo, C., Vadez, V., Whitbread, A.M., Siddique, K.H.M., Nguyen, H.T., Carberry, P.S., Bergvinson, D., 2018. Accelerating genetic gains in legumes for the development of prosperous smallholder agriculture: integrating genomics, phenotyping, systems modelling and agronomy. J. Exp. Bot. 69, 3293-3312. https://doi.org/10.1093/jxb/ery088, 2018.

VDLUFA, 1991. VDLUFA Methodenhandbuch Band 1. Die Untersuchung Von Böden. 4. Auflage. VDLUFA-Verlag, Darmstadt, Germany. ISBN 978-3-941273-13-19.

Weigelt, A., Jolliffee, P., 2003. Essay review. Indices of plant competition. J. Ecol. 91, 707-720. https://doi.org/10.1046/j.1365-2745.2003.00805.x. 